\title{
MODAL INTELEKTUAL PADA INOVASI SEKTOR PARIWISATA DI YOGYAKARTA
}

\author{
Heri Susanto, Rosita, Rudi Prasetyo Ardi \\ AA YKPN Yogyakarta \\ Email: herisusanto303@gmail.com
}

\begin{abstract}
An organization's ability to innovate depends on its intellectual capital. Our study attempts to examine the influence of individual components of intellectual capital on corporate innovation. This article proposes a method of classifying and measuring intellectual capital, highlighting the following three components. Human capital, organizational capital and social capital. Our goal is to explain a company's performance in the field of innovation and highlight the importance of each oneDimension of intellectual capital for a certain type of innovation (product, process, marketing and organization). For this purpose, a survey was carried out among 80 participating SMEs in the Yogyakarta tourist area. Company data was analyzed using SPSS using regression data analysis techniques through the developed hypothesis.
\end{abstract}

Keywords : intellectual capital, social capital, human capital, organisation capital innovativeness, Tourism.

DOI: http://dx.doi.org/10.29040/jap.v22i1.2493

\section{PENDAHULUAN}

COVID-19 telah menyebar ke seluruh negara di dunia. Virus mematikan ini telah berdampak buruk pada pemerintah, masyarakat, perawatan kesehatan, pendidikan, bisnis, dan ekonomi. Saat para peneliti dan ilmuwan di seluruh dunia sedang mencari obatnya, virus tetap mematikan, dan tingkat infeksinya terus meningkat. UKM di seluruh dunia telah terpengaruh oleh pandemi global ini. Karena banyak negara memberlakukan lockdown, UKM menjadi salah satu yang paling rentan di sektor bisnis dan menderita kerugian finansial yang sangat besar.

Berdasarkan kerangka kerja kami, kami berpendapat bahwa sektor pariwisata dapat berkembang dengan bantuan pendekatan yang fleksibel dari pemerintah, pelaku pasar, inovator, dan tenaga kerja industri. Ini akan menjadi lebih permanen setelah pandemi. Partisipasi masyarakat dalam perjalanan ini sangat penting karena pelarangan perjalanan ke luar negeri mungkin memakan waktu lebih lama dari perkiraan. Perkembangan tersebut tidak hanya memperluas basis industri pariwisata, tetapi juga memberikan peluang untuk lebih mengembangkan destinasi wisata yang tertinggal. Pemain utama dalam pariwisata harus melanjutkan kelangsungan hidup setelah epidemi. Tetapi dengan bekerja dalam perlawanan kami, pemain muda pasti bisa menang dan menjamin kesejahteraan seluruh komunitas dengan mendorong pariwisata berkelanjutan.

Industri pariwisata Indonesia terkena dampak wabah covid-19, termasuk Yogyakarta. Tingkat hunian hotel di Yogyakarta telah mencapai titik terendah akibat penurunan jumlah tamu hotel dan aktivitas komersial (Alexander, 2020).

Seperti yang dicatat Rivera (2020), penelitian tentang industri perhotelan dan pariwisata sangat penting untuk epidemi. Para peneliti mulai fokus pada bidang ini, tetapi sejauh ini sangat sedikit pekerjaan yang mungkin dilakukan. Dalam survei yang dilakukan oleh database Web Industry of Science, hanya 45 survei yang dilakukan untuk menyelidiki dampak COVID-19 pada industri pariwisata. Studi ini juga menunjukkan tantangan di mana-mana dan terarah di bidang ini. Perbedaan studi ini tidak berdampak signifikan pada pengetahuan dan 
hanya bermanfaat bagi pembuat kebijakan dan pemangku kepentingan.

Banyak peneliti modal intelektual (Stewart, 1991). (Subramaniam and Youndt, 2005; Delgado, 2011). (Cabrita \& Bontis, 2008) (Anatolievna, Molodchik, Anatolievna, \& Barajas, 2014) Edvinsson and Malone (1997) Mewakili lingkungan dunia bisnis saat ini. Agar fungsinya bisa berjalan, usaha kecil dan menengah (UKM) hanya bisa sukses dengan bantuan modal intelektual. Seiring persaingan global yang semakin ketat, banyak perusahaan di seluruh dunia telah berkinerja baik. Organisasi perlu mengidentifikasi dan mengelola elemen kunci yang lebih efisien dan efektif. Studi ini menyarankan agar UMKM mempelajari sumber daya dan fitur dengan terlebih dahulu melakukan analisis internal untuk meningkatkan kinerja.

Aset tidak berwujud yang kuat memungkinkan usaha kecil dan menengah bersaing untuk meningkatkan pengaruhnya dan membedakan diri dari pesaing dalam lingkungan bisnis yang berkembang. Oleh karena itu, dalam penelitian ini prinsip modal intelektual dijadikan sebagai prinsip dasar. Teori Modal Intelektual UKM menggunakan aset tidak berwujud untuk meningkatkan kinerja. Modal intelektual adalah katalisator yang menghasilkan produk dan layanan bernilai tambah serta meningkatkan kinerja UKM. Usaha kecil dan menengah harus kompeten dan inovatif, berkembang dan hidup dalam lingkungan bisnis yang sangat kompetitif dan dinamis. Oleh karena itu, usaha kecil perlu memahami hubungan antara modal intelektual dan kinerja.

Kemampuan suatu perusahaan untuk bekerja dan tumbuh dengan sukses dipengaruhi oleh banyak faktor lingkungan. Modal intelektual adalah salah satu dimensi lingkungan internal perusahaan dan oleh karena itu merupakan faktor penting dalam strategi manajemen. Itu telah disepakati Kegiatan inovasi dapat mempengaruhi daya saing dan akibatnya kinerja dari sebuah perusahaan. Dalam konteks pariwisata, hanya sedikit penelitian yang berfokus pada lingkungan karakteristik seperti modal intelektual, sebagai faktor kunci untuk inovasi. Karena itu,studi ini menjembatani kesenjangan ini dengan menganalisis hubungan antara modal intelektual (termasuk tiga dimensi menurut Subramaniam dan Youndt 2005).
UKM merupakan tulang punggung industri pariwisata nasional, dan usaha bisnisnya sangat cepat dan inovatif. Di luar bentuk berwujud seperti paten dan merek dagang, berbagai modal intelektual tidak berwujud seperti pengetahuan dan keterampilan manusia dapat disediakan Tajeddini, K. (2010). Selain itu, setiap negara di dunia menginginkan destinasi terbaik untuk menarik wisatawan. Di seluruh dunia. Usaha kecil dan menengah yang beroperasi di sektor pariwisata bisa mendapatkan banyak uang dalam hal cadangan devisa, pertumbuhan ekonomi dan pembangunan. Pariwisata dapat meningkatkan budaya, tradisi, makanan, dan citra daerah suatu negara.

Secara khusus penelitian ini menghipotesiskan bahwa dimensi modal intelektual mempengaruhi inovasi perusahaan. Dengan menganalisis efek dari modal intelektual pada inovasi dan sebagai tambahan pada pertumbuhan perusahaan, penelitian ini memberikan kontribusi untuk pemahaman yang lebih baik tentang bagaimana strategi manajemen yang mengembangkan modal menghasilkan pengaruh yang berbeda terhadap kinerja perusahaan.

Di sektor pariwisata, permintaan pelanggan adalah generator inovasi yang kuat. Sisi penawaran pariwisata harus terus beradaptasi dengan turis (Weiermair, 2006). Kami setuju bahwa turis baru berpura-pura berpengalaman dan fleksibel. Inilah alasan mengapa perusahaan pariwisata harus merespons gaya hidup baru secara efisien dan dengan demikian mendukung inovasi (Crnogaj, Rebernik, Hojnik, \& Gomezelj, 2014). Bertujuan untuk tetap kompetitif, perusahaan pariwisata dan juga destinasi pariwisata dipaksa untuk mengembangkan dan menawarkan layanan baru atau yang diperbarui, sehingga mereka diwajibkan untuk melakukan inovasi (Scheidegger, 2006;). Inovasi dalam bisnis pariwisata telah diteliti oleh Weiermair, Peters, dan Frehse (2005), Orfila-Sintes et al. (2005), Hipp dan Grupp (2005) dan Pikkemaat dan Weiermair (2007). Inovasi dapat dipahami sebagai alat kunci untuk mencapai daya saing. Modal intelektual merupakan salah satu sumber daya dalam perusahaan yang memberikan nilai tambah bagi pemangku kepentingan (Shakina \& Barajas, 2014). Untuk tujuan studi mereka (Anatolievna, Molodchik, Anatolievna, \& 
Barajas, 2014) membagi tiga komponen modal intelektual (modal manusia, sosial dan organisasional) dan mendefinisikan enam dimensi modal intelektual, yaitu kapabilitas manajemen, kapabilitas sumber daya manusia, kapabilitas inovasi, kapabilitas proses internal, kapabilitas jaringan, dan loyalitas pelanggan.

Mempertimbangkan literatur terdahulu, kami mengusulkan model penelitian (Gambar 1) yang menggabungkan dimensi modal intelektual, dan inovasi. Dengan menggunakan model ini kami menyusun hipotesis berikut;

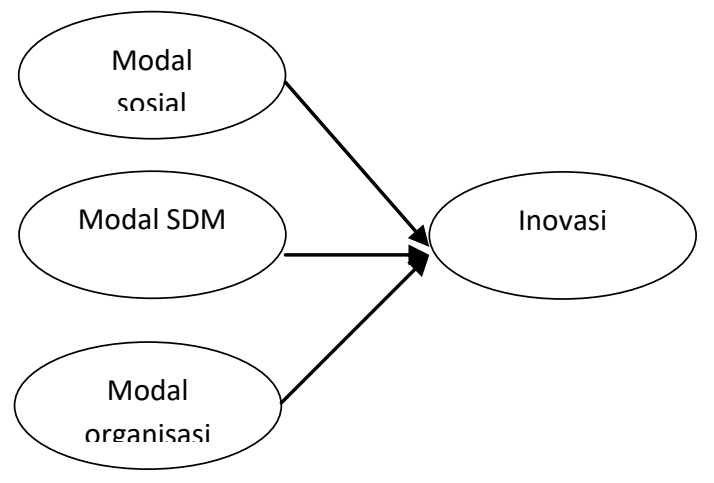

Gambar 1. Model Penelitian

Hipotesis 1. Modal sosial berhubungan (signifikan secara statistik) dengan inovasi. Hipotesis 2. Modal manusia berhubungan (signifikan secara statistik) dengan inovasi. Hipotesis 3. Modal organisasi berhubungan (signifikan secara statistik) dengan inovasi.

\section{METODE PENELITIAN}

Penelitian ini menggunakan data primer melalui kuesioner (Sugiono, 2014). Data diperoleh melalui kuesioner terstruktur dari para pelaku UMKM yang terlibat dalam berbagai kegiatan di sektor pariwisata di Yogyakarta. Para peneliti mengumpulkan instrumen pertanyaan yang dikembangkan oleh Nieves et al. (2014) dan Gomezelj. Omerzel (2014). Kuesioner ini diukurmenggunakan skala likert 5 poin, di mana $1=$ sangat tidak setuju dan $5=$ sangat setuju.

Di dalam studi, modal intelektual diukur dengan tiga dimensi yang berbeda; modal sosial (empat item; yaitu: [1] karyawan kami terampil dalam berkolaborasi satu sama lain untuk mendiagnosis dan menyelesaikan masalah; [2] karyawan kami saling berbagi informasi dan belajar dari satu sama lain; [3] kamikaryawan berinteraksi dan bertukar ide dengan orang-orang dari berbagai area perusahaan; dan [4] karyawan kami menerapkan pengetahuan dari satu area perusahaan ke masalah dan peluang yang muncul di tempat lain), sumber daya manusia (empat item; yaitu: [1] karyawan kami secara luas dianggap sebagai yang terbaik di industri kami; [2] karyawan kami kreatif dan cerdas; [3] karyawan kami ahli dalam pekerjaan dan fungsi khusus mereka; dan [4] karyawan kami mengembangkan ide dan pengetahuan baru), dan modal organisasi (tiga item; yaitu: [1] kami organisasi menggunakan paten dan lisensi sebagai cara untuk menyimpan pengetahuan; [2] organisasi kami budaya (cerita, ritual) berisi ideide berharga, cara berbisnis, dll; dan [3] milik kita organisasi menanamkan banyak pengetahuan dan informasinya dalam struktur, sistem, dan proses).

Inovasi diukur dengan empat dimensi, yaitu produk / jasa (5 item; yaitu: [1] Kami telah memperkenalkan banyak layanan baru ke pasar; [2] kami punya memperkenalkan banyak modifikasi pada layanan yang sudah ada; [3] organisasi kami terus mencari untuk layanan baru; [4] kami telah memperkenalkan lebih banyak layanan baru daripada pesaing kami; dan [5] layanan baru yang kami perkenalkan telah menyebabkan perubahan signifikan dalam industri), proses (5 item; yaitu.; [1] kami sering memperbarui metode penyampaian layanan untuk meningkatkan produktivitas; [2] kami sering menggabungkan teknologi untuk meningkatkan efisiensi; [3] kami sering memasukkan teknologi untuk meningkatkan kualitas layanan kami; [4] kami melakukan investasi besar untukmemasukkan teknik, peralatan, dan / atau program komputer baru; dan [5] kami sering melatih staf kami dalam teknologi baru di sektor ini), pemasaran (5 item; yaitu: [1] kami dinamis dalam mengembangkan dan menggunakan saluran penjualan baru; [2] kami sering memperkenalkan teknik baru atau saluran untuk mempromosikan layanan kami; [3] kami sering memperkenalkan metode baru untuk memberi harga pada layanan kami; [4] pesaing kita menggunakan metode pemasaran kita sebagai titik acuan; dan [5] metode pemasaran baru yang kami gabungkan merupakan hal baru di sektor ini), dan organisasi (empat item; yaitu: [1] kami sering memperkenalkan perubahan 
organisasi meningkatkan pembagian tanggung jawab dan pengambilan keputusan; [2] sering kami perkenalkan metode baru untuk mengelola hubungan eksternal dengan perusahaan atau lembaga publik lain; [3] kami sering memperkenalkan praktik baru dalam organisasi kerja atau prosedur perusahaan; dan [4] metode organisasi baru yang kami gabungkan telah menjadi pelopor di sektor ini).Skala ini sudah digunakan dan diuji secara empiris oleh Nieves et al. (2014) dan Gomezelj Omerzel (2014).

Subjek penelitian ini adalah pelaku UMKM di Yogyakarta yang berjumlah 340 jiwa (Bappeda DIY, 2020) dengan jumlah sampel 80 responden dari pelaku UMKM yang dipilih secara acak. Hasil kuesioner dianalisis menggunakan program SPSS. dan uji reliabilitas. Selain itu dilakukan uji penerimaan klasikal yang terdiri dari uji normalitas, uji multikolinieritas dan uji heteroskedastisitas.Pengujian hipotesis menggunakan analisis regresi linier berganda.

Variabel penelitian ini adalah modal Sosial (X1), Modal SDM (X2) dan modal Organisasi (X3) sebagai variabel dependen sedangakan Inovasi (Y) sebagai variabel dependen. Dengan persamaan regresi sebagai berikut :

$$
\mathrm{Y}=\mathrm{a}+\mathrm{b} 1 \mathrm{X} 1+\mathrm{b} 2 \mathrm{X} 2+\mathrm{b} 3 \mathrm{X} 3+\mathrm{e}
$$

Dimana :

$\mathrm{a}=$ Konstanta

$\mathrm{b} 1, \mathrm{~b} 2, \mathrm{~b} 3=$ Koefisien determinasi

$\mathrm{Y}=$ Inovasi

$\mathrm{X} 1$ = Modal Sosial

$\mathrm{X} 2=$ Modal SDM

X3 = Modal organisasi

$\mathrm{e}=$ eror

\section{HASIL DAN PEMBAHASAN}

\subsection{Hasil penelitian}

Lakukan pemeriksaan validitas untuk melihat apakah alat yang dikompilasi benar-benar dapat mengukur apa yang Anda butuhkan. Uji validitas digunakan untuk mengukur bagaimana alat yang sah menyimpan informasi tentang variabel yang telah diperiksa dengan benar. Jika dipastikan kuesioner dapat mengungkapkan apa yang diukur dengan kuesioner tersebut maka kuesioner tersebut dianggap valid (Ghozali, 2017). Berdasarkan hasil uji validitas Skor Bartlett di bawah 0,5.

Uji reliabilitas statistik digunakan untuk mengetahui apakah pengumpul statistik memiliki tingkat akurasi, akurasi, stabilitas, atau konsistensi, serta menggunakan nilai Cronbach alpha> 0,6 untuk mencapai reliabilitas sehingga semua variabel penelitian valid dan reliabel. Pengujian ini merupakan pengujian terhadap data berdistribusi normal, dan ditampilkan dalam keluaran SPSS melalui kurva histogram dan kurva grafik pp untuk menunjukkan jumlah record penelitian. Data normal didistribusikan di semua area kurva normal, dan kumpulan data dengan distribusi abnormal terletak di kiri dan kanan garis kurva normal.

Uji normalitas dilakukan untuk mengetahui apakah variabel dependen dan variabel independen berdistribusi normal dalam regresi (Ghozali: 2017). Untuk mengetahui apakah sebaran data normal dapat ditemukan, ada dua metode pencarian, yaitu penggunaan analisis grafis dan pengujian statistik. Hasil pengujian dianalisis menggunakan grafik. $k$ P-P menunjukkan bahwa model regresi berdistribusi normal karena titik-titiknya memanjang di sekitar diagonal dan sebarannya sepanjang diagonal.Untuk memperkuat uji normalitas, Anda dapat melakukan uji Kolmogrov-Smirnov pada sampel. Uji Kolmogrov-Smirnov yang menentukan sampel didasarkan pada apakah nilai probabilitas residual melebihi 0,05 atau $5 \%$. Tabel 1 menunjukkan hasil uji sampel tunggal Kolmogrov-Smirnov sebagai berikut :

Tabel 1. Hasil Uji Normalitas Data

\begin{tabular}{|c|c|c|c|}
\hline Variabel & $\begin{array}{c}\text { Kolmog } \\
\text { orov- } \\
\text { Smirno } \\
\mathbf{v ~ Z}\end{array}$ & $\begin{array}{c}\text { Asymp. } \\
\text { Sig. } \\
\text { (2-tailed) }\end{array}$ & Keterangan \\
\hline & 0,63 & 0,06 & $\begin{array}{c}\text { Terdistribusi } \\
\text { Normal }\end{array}$ \\
\hline
\end{tabular}

Sumber : Data primer diolah, 2021 
Berdasarkan uji normalitas dengan menggunakan uji satu sampel KolmogrovSmirnov terlihat bahwa skor KolmogrovSmirnov untuk variabel residual sebesar 0,602 dan signifikansi 0,763 lebih besar dari 0,05.

\section{Uji Multikolinearitas}

Uji multikolinieritas bertujuan untuk mengetahui apakah model regresi dapat menemukan korelasi antar variabel independen. Model regresi yang baik seharusnya tidak menghasilkan korelasi antar variabel independen. Multikolinieritas juga dapat dilihat dari nilai toleransi (TOL) dengan menggunakan metode variance inflation factor (VIF). Nilaicuto $\mathrm{ff}$ yang biasa digunakan untuk menunjukkan adanya multikolinearitas adalah nilai toleransi >10 (Ghozali: 2017). Berikut hasil uji multikolinearitas sebagai berikut:

Tabel 2. Hasil Uji Multikolinearitas

\begin{tabular}{|l|c|c|l|}
\hline Variable & tolerance & VIF & \multicolumn{1}{|c|}{ Keterangan } \\
\hline $\begin{array}{l}\text { Modal } \\
\text { Sosial }\end{array}$ & 0,898 & 1,222 & $\begin{array}{l}\text { tidak terjadi } \\
\text { multikoliniaritas }\end{array}$ \\
\hline $\begin{array}{l}\text { Modal } \\
\text { SDM }\end{array}$ & 0,878 & 1,354 & $\begin{array}{l}\text { tidak terjadi } \\
\text { multikoliniaritas }\end{array}$ \\
\hline $\begin{array}{l}\text { Modal } \\
\text { Organisasi }\end{array}$ & 0,786 & 1,369 & $\begin{array}{l}\text { tidak terjadi } \\
\text { multikoliniaritas }\end{array}$ \\
\hline
\end{tabular}

Sumber: Data primer diolah, 2021

Berdasarkan hasil uji multikolinearitas dapat diketahui bahwa semua variabel independen menunjukkan tidak terjadi mulitikolinearitas karena nilai tolerance $>0,10$ dan nilai VIF $<10$.

\section{Uji Autokolerasi}

Pengujian ini dilakukan untuk memeriksa apakah terdapat korelasi antara kesalahan pengguna pada periode $\mathrm{t}$ dan kesalahan pada periode $\mathrm{t}-1$ atau sebelumnya pada model regresi linier (Ghozali: 2017). Berikut adalah hasil uji kapasitas diri dengan menggunakan uji Durbin-Watson (DW):

Tabel 3. Nilai Durbin Watson

$$
\begin{array}{l|l}
\text { Nilai Durbin Watson } & 2,540
\end{array}
$$

Sumber: Data primer diolah, 2021

Hasil uji autokorelasi yang telah dilakukan diketahui bahwa nilai durbin-watson $=2,540$, dengan jumlah responden 80 diketahui dl 1,546 du 1,187. Batas maksimal dw adalah $4-1,546=$ 2,454, jadi karena $1,546<2,440<2,454$ maka tidak terjadi autokorelasi pada data.

\section{Uji Heteroskedaskisitas}

Uji heteroskedastisitas bertujuan untuk menguji ketimpangan varian residual dari satu observasi ke observasi lainnya dalam model regresi (Ghozali, 2017). Uji heteroskedastisitas dilakukan dengan mengembalikan nilai sisa absolut dengan variabel independen, atau Anda dapat menggunakan scatter plot.

Grafik 1. Uji Hesteroskedastisitas

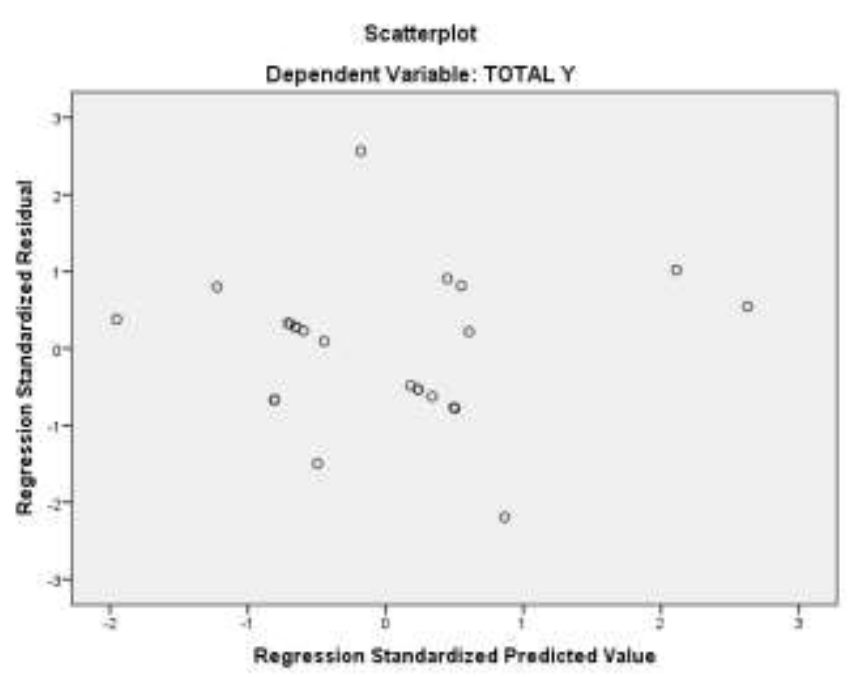

Terlihat jelas dari scatter plot di atas bahwa karena titik memiliki lebar yang tidak beraturan di atas dan di bawah sumbu 0 sumbu Y, maka tidak terdapat pola yang spesifik. Dapat disimpulkan bahwa tidak terdapat heteroskedastisitas atau penerimaan $\mathrm{H} 0$.

\section{Uji Statistik t}

Uji statistik menunjukkan sejauh mana pengaruh variabel independen secara parsial dalam menjelaskan variasi variabel dependen. Variabel independen dimaksudkan untuk mempengaruhi variabel dependen secara parsial jika tingkat signifikansinya< 0,05 (Ghozali, 2017).

\section{Tabel 4. Hasil Uji T}

\begin{tabular}{|l|r|r|r|l|}
\hline Variabel & Thitung & Ttabel & \multicolumn{1}{c|}{ sig. } & Keterangan \\
\hline Modal & 0,813 & 1,984 & 0 & Berpengaruh \\
Sosial & & & & \\
\hline Modal & 3,783 & 1,984 & 0 & \\
SDM & 0.876 & 1,987 & 0 & Berpengaruh \\
\hline
\end{tabular}


Modal Organisasi

Berpengaruh

Dari hasil pengujian regresi Tabel hasil uji statistik t menunjukkan bahwa

\section{Modal \\ SDM \\ Berpengaruh}

\section{Uji F}

Uji F menunjukkan apakah semua variabel independen mempunyai pengaruh simultan terhadap variabel dependen. Variabel independen dikatakan berpengaruh terhadap variabel dependen secara simultan apabila taraf signifi kansi < 0,05 (Ghozali, 2017)

Tabel 5. Hasil Uji F

\begin{tabular}{|l|r|r|c|}
\hline \multicolumn{1}{|c|}{ Variabel } & \multicolumn{1}{c|}{ Fhitung } & sig. & Keterangan \\
\hline Modal Sosial & 12,432 & 0 & Berpengaruh \\
\hline $\begin{array}{l}\text { Modal SDM } \\
\text { Modal } \\
\text { Organisasi }\end{array}$ & & & \\
\hline
\end{tabular}

Hasil uji $F$ dapat diuraikan bahwa bahwa variabel Modal Sosial, Modal SDM dan modal organisasi berpengaruh secara simultan terhadap berpengaruh terhadap Inovasi.

\section{Uji Determinasi (R2)}

Analisis regresi digunakan untuk mengetahui pengaruh satu atau lebih variabel independen terhadap variabel dependen. Hasil penelitian ini menemukan bahwa hasil uji koefisien determinasi pada tabel di atas menunjukkan bahwa Adjusted R2 sebesar 0,295 atau 29,5\% yang berarti variabel sosial dan modal manusia akan mempengaruhi inovasi. Mereka adalah $29,5 \%$, sedangkan $70,5 \%$ variabel lainnya dijelaskan oleh penelitian ini.

\section{KESIMPULAN}

Artikel ini menawarkan representasi dari penelitian yang dilakukan di industri pariwisata DIY. Penelitian mencoba untuk menguji korelasi antara modal intelektual individu dan inovasi perusahaan. Kami mengusulkan metode klasifikasi dan pengukuran modal intelektual, menyoroti tiga komponen berikut; modal manusia, modal organisasi, dan modal sosial.

Dari semua variabel yang diukur memiliki pengaruh yang signifikan.

Tujuan kami adalah untuk menjelaskan kinerja inovasi dengan menunjukkan pentingnya setiap dimensi modal intelektual pada jenis tertentu terhadap inovasi (produk, proses, pemasaran, dan organisasi).

Artikel kami berkontribusi, pertama, untuk pemahaman tentang inovasi dalam bisnis pariwisata. Minat dalam subjek ini akan terus berkembang. Pentingnya inovasi untuk bisnis pariwisata dan pariwisata daya saing industri telah diakui oleh peneliti dan praktisi. Itu sektor pariwisata memiliki karakteristik khusus, dan faktor manusianya sangat penting (Camisón \& Monfort-Mir, 2012). Oleh karena itu, inovasi pariwisata sangat bergantung pada modal intelektual perusahaan.

Inovasi, sebagai keluaran dari berbagai faktor lingkungan perusahaan, termasuk modal intelektual, dan di sisi lain sebagai faktor yang mempengaruhi kinerja perusahaan, memiliki baru-baru ini mendapat banyak perhatian dari para sarjana, manajer, dan pemerintah. Namun, tidak ada studi yang relevan mengeksplorasi hubungan antara dimensi modal organisasi dan inovasi.

\section{REFERENSI}

Amana, R. (2020). 80 Persen Hotel dan Restoran di Tangsel Tutup Akibat Pandemi Covid19, Sejumlah Karyawan Kena PHK. Warkota.Tribunnews.

https://wartakota.tribunnews.com/2020/04/ 13/80-persen-hotel-dan-restorandi-tangseltutup-akibat-pandemi-covid-19-sejumlahkaryawan-kena-ph.

Anatolievna, M., Molodchik, E., Anatolievna, S., \& Barajas, A. (2014). Metrics for the elements of intellectual capital in an economy driven by knowledge. Journal of Intellectual Capital, 15, 206-226.

Ariyanto. 2005. Ekonomi Pariwisata. Penerbit Rineka Cipta. Jakarta

Bontis, N. (1998). Intellectual capital: An exploratory study develops measures and model. Management Decision, 36, 63-76 
http://bappeda.jogjaprov.go.id/

Cabrita, M. R., \& Bontis, N. (2008). Intellectual capital and business performance in the Portuguese banking industry. International Journal of Technology Management, 43, 212-237.

Crnogaj, K., Rebernik, M., Hojnik, B. B., \& Gomezelj, D. (2014). Building a model of researching the sustainable entrepreneurship in the tourism sector. Kybernetes, 43, 377-393.

Ghozali, Imam dan Ratmono, Dwi. 2017. Analisis Multivariat dan Ekonometrika dengan Eviews 10. Badan Penerbit Universitas Diponegoro: Semarang.

Gorbalenya, Alexander E. 2020. Severe acute respiratory syndrome-related coronavirus - The species and its viruses, a statement of the Coronavirus Study Group. bioRxiv.

Hipp, C., \& Grupp, H. (2005). Innovation in the service sector: The demand for servicespecific innovation measurement concepts and typologies. Research Policy, 34, 517535 .

Shakina, E., \& Barajas, A. (2014). Value creation through intellectual capital in developed European markets. Journal of Economic Studies, 41, 272-291.

Subramaniam, M., \& Youndt, M. A. (2005). The Influence of intellectual capital on the types of innovative capabilities. Academy of Management Journal, 48, 450-463.

Scheidegger, E. (2006). Can state promote innovation in tourism? Should it?. In OECD (Eds.), Innovation and Growth in Tourism(pp. 11-15). Paris: OECD.

Sugiyono. (2017). Metode Penelitian Kuantitatif, Kualitatif, dan R\&D. Bandung: Alfabeta

Tajeddini, K. (2010). Effect of customer orientation and entrepreneurial orientation on innovativeness: Evidence from the hotel industry in Switzerland. Tourism Management, 31, 221-231.

Weiermair, K. (2006). Product improvement or innovation: What is the key to success in tourism?. In OECD (Eds.), Innovation and Growth in Tourism (53-67). Paris: OECD. 